\title{
SUBCUTANEOUS FAT NECROSIS OF THE NEWBORN WITH CALCIFICATION OF THE TISSUES
}

\author{
BY \\ MARGARET M. MARTIN and ELUNED M. STEVEN \\ From the Elsie Inglis Memorial Maternity Hospital, Edinburgh
}

(RECEIVED FOR PUBLICATION OCTOBER 14, 1956)

The following case is of interest as it presents some features of subcutaneous fat necrosis not previously described. Calcification of the tissues was seen radiologically and a raised serum calcium level caused symptoms similar to those of idiopathic hypercalcaemia.

\section{Case Report}

A girl weighing $7 \mathrm{lb} .14 \mathrm{oz}$. was born at the Elsie Inglis Memorial Hospital in August, 1953. The child was a breech presentation with extended legs and after a long, inert labour of 66 hours was born by breech extraction.

The mother was 38 and this baby was her first after 15 years of marriage. There had been two previous miscarriages. This baby also nearly miscarried at eight weeks and her mother had to rest in bed for one month at that time. Otherwise the pregnancy progressed satisfactorily. The pelvic measurements were normal.

At birth the baby was limp and a poor colour for several days. She had petechial haemorrhages over the face and bilateral subconjunctival haemorrhages. She was rather irritable and had a shrill cry which settled with sedatives.

On the second day after birth she developed marked oedema of the limbs and trunk which did not pit on pressure, the skin being tightly stretched.

On the fifth day after birth, sharply defined areas of subcutaneous induration could be felt in the back, shoulders and thighs, and the overlying skin was bluish red.

On the ninth day the swelling in the left thigh became soft and fluctuant and thick, brownish-yellow fluid was aspirated and sent for culture, and on the following day the 'abscess' had to be opened. Both these specimens were reported sterile.

During this time the general condition of the baby was good. She was hungry, gained weight and had no temperature.

A few days later another area of softening developed in the thigh and other indurated lumps appeared in the other thigh, anterior chest wall and groin and both buttocks became very hard, the skin over them being hot, red and angry. Except on the buttocks the skin over the new lesions was not red. The lumps were now discrete, indurated areas freely movable over muscle and not attached to the skin.
When 1 month old the temperature was raised for the first time and from this moment the baby became listless and reluctant to take her feeds and she failed to gain weight. She also started to vomit after feeds. She was not breast fed.

Haemoglobin was $120 \%$, leucocytes 10,300 (eosinophils $3 \%$, neutrophils $30 \%$, lymphocytes $62 \%$, monocytes $3 \%$ ).

The urine contained albumin and granular casts and was acid, previously having been normal and alkaline.

The temperature swung from $101^{\circ}$ to $103^{\circ} \mathrm{F}$., but several blood cultures were sterile.

Radiographs showed some fuzziness in the subcutaneous tissues just where the areas of induration were to be felt.

Biopsy of a nodule led to the diagnosis of fat necrosis with calcification.

Pathological Report. The pathological report was as follows:

Macroscopical Features. The specimen is a small piece of skin with subjacent subcutaneous fatty tissue. In the latter is a rather ill-defined indurated mass, part of which has a whitish appearance.

MicROSCOPICAL REPORT. The epidermis and dermis are healthy. The whitish subcutaneous nodule appears in the section as a small cavity in the fatty tissue filled with structureless necrotic debris and lumps of calcareous material. The wall of this cavity is formed by a layer of fibrous granulation tissue showing a vigorous foreign body reaction. Many of the giant cells contain acicular spaces that have been occupied by crystals, probably of cholesterin. This foreign body reaction extends to some distance from the cavity, along the fibrous septa between the fat lobules. The fatty tissue in these places shows necrotic changes: the fat cells are large, the cell membranes are ill-defined and stain bluish and most of the nuclei have disappeared. Small calcified particles occur in many of these areas. Only in one small area is there some infiltration by polymorph leucocytes; this is at some distance from the cavity, and is a relatively sparse infiltration, not an abscess.

INFERENCE. At the stage now reached by the lesion it is impossible to tell what it was in the beginning. The foreign body reaction appears to have been evoked by fat necrosis, and the calcification to have occurred in necrotic fat. There is 
extremely little to suggest a pyogenic infection, which, if present initially, must have died out some time ago.

\section{(Sgd.) A. R. MACGregor.}

Another radiograph taken when the baby was 7 weeks old showed definite calcification in the subcutaneous tissues (Fig. 1).

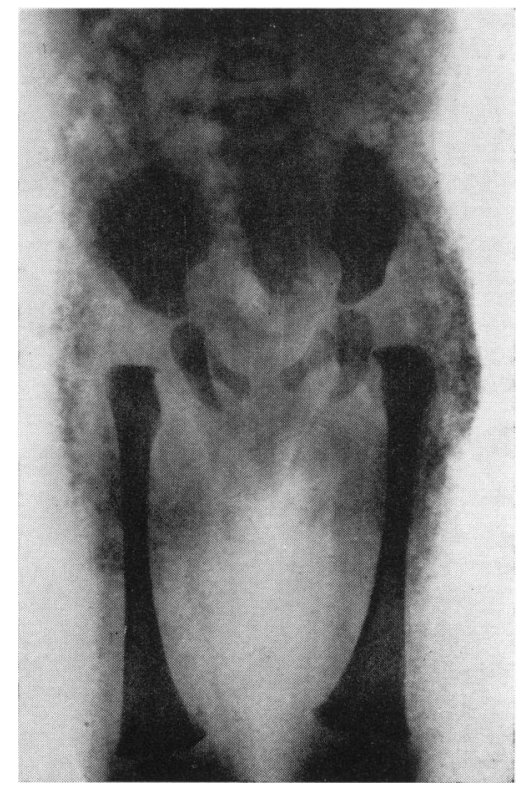

Fig. 1.

The serum calcium level estimated at this time was $12 \mathrm{mg}$. \%.

The baby was kept in hospital until she was $2 \frac{1}{2}$ months old as her temperature remained high, rising to $103-104^{\circ} \mathrm{F}$. and was not affected by any antibiotics, although a wide variety were tried.

There were remissions when the temperature remained at $99^{\circ} \mathrm{F}$., but these were not due to the treatment.

Her general condition, however, was quite good; she was gaining weight slowly and was quite lively, so she was sent home.

Unfortunately we were unable to see her again until she was 7 months old. At this time she weighed only $11 \mathrm{lb} .7 \mathrm{oz}$., was frequently sick and was only gaining about 2 oz. a week. She had no appetite, her muscle tone was poor but she was no longer running a temperature. However, she was bright and lively and had a high colour. There were a few lumps to be felt now although there was considerable fibrosis beneath the scars where the two incisions had been made. She was not able to sit up and the anterior fontanelle was nearly closed.

The serum calcium level was $13.9 \mathrm{mg}$. \%. The results of other investigations are tabulated.

Calcification of the tissues seen radiologically was substantially the same.

Her vitamin D intake was stopped.

The urine was acid (S.G. 1001).

Progress continued to be very slow indeed due to continued vomiting so she was readmitted to hospital when she was 10 months old and put on a low-calcium diet (serum calcium content, 13.3 mg. \%), but her weight decreased on this régime and it was therefore discontinued.

Results of investigations at the time were substantially the same. The blood urea nitrogen and serum calcium levels were still raised. Radiographs showed that the calcification in the tissues was diminishing.

She started to make progress while in hospital, vomiting ceased and the weight increased.

She was seen again when 1 year old (weight, $20 \mathrm{lb}$.); she had just sat up without support. She had eight teeth and the anterior fontanelle was practically closed. At no stage was a systolic murmur heard as noted by some workers.

At 15 months she was eating much better, not vomiting at all and gaining $4 \mathrm{oz}$. a week; she was lively and muscle tone was good.

A radiograph showed that calcification in the soft tissues had now practically disappeared and only traces were still apparent in the right buttock. The serum calcium was now normal but the B.U.N. was still raised. Another radiograph taken when she was 2 years old was normal.

\section{Discussion}

Very few cases of subcutaneous fat necrosis have been reported where calcification in the tissues has been demonstrated radiologically.

Harrison and McNee (1926) reported two cases with calcification shown radiologically; one of these children died, but the other recovered. In the fatal case the serum calcium level during the illness was

TABLE

RESULTS OF INVESTIGATIONS AT DIFFERENT AGES

\begin{tabular}{|c|c|c|c|c|c|c|c|}
\hline & & 7 Weeks & 10 Weeks & 7 Months & 10 Months & 15 Months & 2 Years \\
\hline 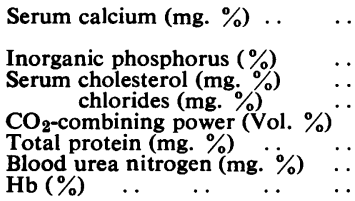 & $\begin{array}{l}\cdots \\
\cdots \\
\cdots \\
\cdots \\
\cdots \\
\cdots \\
\cdots\end{array}$ & 12 & $\begin{array}{r}10 \cdot 3 \\
127^{3 \cdot 5}\end{array}$ & $\begin{array}{c}13 \cdot 9 \\
\text { repeated } \\
4 \cdot 2 \\
660 \\
67 \cdot 5 \\
6 \cdot 9 \\
30 \\
70\end{array}$ & $\begin{array}{l}13 \cdot 3 \\
4 \cdot 4 \\
170 \\
570 \\
\\
32 \\
80\end{array}$ & $\begin{array}{l}540 \\
6 \cdot 4 \\
27\end{array}$ & 10 \\
\hline
\end{tabular}


$9.3 \mathrm{mg} . / 100 \mathrm{ml}$. In the other the serum calcium level was $15 \mathrm{mg}$. at 6 months of age, at 9 months $11.8 \mathrm{mg}$., while calcification seen in the radiograph persisted but diminished in amount over a few months.

Morse (1921) reported a child showing calcification radiologically at $3 \frac{1}{2}$ years, but did no follow up.

Bernheim-Karrer (1933) described 15 cases of subcutaneous fat necrosis and only one is mentioned as showing calcification in a radiograph taken at 4 weeks of age: this had disappeared by $7 \frac{1}{2}$ months.

The latter authors do not record the serum calcium levels in their cases. Clay (1956) reported a case of extensive subcutaneous fat necrosis with massive calcification, in which there was also found a high serum calcium level associated with symptoms of hypercalcaemia.

The case now being reported is similar to Clay's case and also had symptoms of idiopathic hypercalcaemia similar to those described by Payne (1952) and Lightwood (1952), and later Creery (1953) and Lowe, Henderson, Park and McGreal (1954). Like their cases our patient failed to thrive, had anorexia and vomiting associated with wasting, hypotonia and a pink complexion, though without constipation of any degree.

She recovered as soon as the calcium in the subcutaneous tissues disappeared and the serum calcium became normal. As would be expected the recovery was gradual, but she was behaving quite normally at 15 months when the radiographs showed only faint traces of calcium and the serum calcium level was now only $9 \mathrm{mg}$. \%.

No mention is made in the earlier reported cases of the occurrence of the now known symptoms of idiopathic hypercalcaemia following subcutaneous fat necrosis with calcification in early infancy, but many of these cases died in the early stages of the disease.

\section{Summary}

A case of a baby with subcutaneous fat necrosis is described with the unusual features of prolonged calcification of the tissues demonstrable by radiographs and lasting for 15 months. This condition was associated with raised serum calcium levels. While the serum calcium level was raised the patient had symptoms similar to those of idiopathic hypercalcaemia. The symptoms regressed as the calcification disappeared from the tissues and the blood calcium became normal.

\section{REFERENCES}

Bernheim-Karrer, J. (1933). Z. Kinderheilk., 55, 695.

Clay, P. R. (1956). Proc. roy. Soc. Med., 49, 598.

Creery, R. D. G. (1953). Lancet, 2, 17.

Harrison, G. A. and McNee, J. W. (1926). Archives of Disease in Childhood, 1, 63.

Lightwood, R. (1952). Ibid., 27, 302.

Lowe, K. G., Henderson, J. L., Park, W. W. and McGreal, D. A.

Payne, W. W. (1952). Archives of Disease in Childhood, 27, 302. 